УДК $364-7(091)(73)$

DOI:

Ірина Зварич, доктор педагогічних наук, старший науковий співробітник, професор кафедри сучасних європейських мов Київського начіонального торговельно-економічного університету Олег Януш, кандидат філологічних наук, дочент, завідувач кафедри сучасних європейських мов Київького начіонального торговельно-економічного університету

\title{
ІСТОРІЯ РОЗВИТКУ СОЦАЛЬНИХ ПРОГРАМ У США
}

У статті розглядається історія розвитку сочіальних програм у закладах вищої освіти США, висвітлено закономірність і необхідність ӥх прийняття в освітній діяльності; виокремлено історичний етап у розвитку внутрішньої політики США “Новий курс"; зосереджено увагу на змінах протягом історії розвитку освіти, що спонукали до розвитку системи сочіальної допомоги та прийнятття нових сочіальних програм. Слідуючи принципу історизму, ми коротко проаналізували факти, які були поштовхом до прийняття соціальних програм у США і вирішення проблем у системі освіти, які засвідчують, що американська вища освіта постійно змінюється, затверджуючи велику кількість сочіальних програм для ї̈ вдосконалення.

Ключові слова: сочіальна програма; сочіальна допомога; новий курс; науковий пошук; дисертачія; вищі навчальні заклади; реформа; суспільство; навчальний предмет; сучасний розвиток.

Jim. 8.

Iryna Zvarych, Doctor of Sciences (Pedagogy), Senior Researcher, Professor of the Modern European Languages Department Kyiv National University of Trade and Economics Oleh Yanush, Ph.D.(Philology), Associate Professor, Head of the Modern European Languages Department Kyiv National University of Trade and Economics

\section{THE HISTORY OF DEVELOPMENT OF THE SOCIAL PROGRAMS OF THE USA}

The occurrence of mankind in the third millennium is characterized not only by the view of the world community in the future, the reform of higher education, the modernization of Higher Learning Institutions, the demand of higher level of the specialists' training, but also by the significant changes in social, economic, political life of both countries: Ukraine and the United States as well. Ukraine is an independent state that is building the future, reforming the education system, guided by the values of European civilization. The development of education in modern conditions, in particular the reforms in the education system that have taken place in Ukraine and the United States during recent years, has shown that the education as an important link of the national economic system should meet the needs of a particular state and society. That's why, it is necessary to form a single mutually agreed system of the specialists' training of the economy, taking into account the forecast of its development and the national cultural values of a particular country. The education, focusing on the future specialist's needs, should take into account the trends of the entire economy and directions of its development, including the development of social education programs.

This article deals with the history of development of social programs in the USA Higher Learning Institution, and coverage their regularity and necessity adoption into education activity. The history stage of the domestic policy development of the United States "New Course" is singled out. Following the historicism principle, we briefly analyzed the facts which gave the impetus for the adoption of social program of the United States.

Keywords: a social program; social assistance; "New Course"; the scientific research; a dissertation; Higher Learning Institutions; a reform; a society; modern development; a scholarship.

П остановка проблеми. Розвиток освіти в сучасних умовах, зокрема реформи в системі освіти, що відбулися упродовж останніх років в Україні та США, засвідчили, що освіта як важлива ланка національної економічної системи має відповідати потребам конкретної держави і суспільства. Саме тому необхідно побудувати єдину взаємоузгоджену систему підготовки кадрів для економіки, враховуючи прогноз їі розвитку та національні культурні цінності окремої країни. Освіта, зосередившись на потребах кожного майбутнього фахівця, повинна враховувати тенденції всієї економіки і напрямків їі розвитку, зокрема і розвиток соціальних освітніх програм.

Мета статті і завдання. У процесі наукового дослідження розглянути історичний розвиток соціальних програм у вищих навчальних закладах США, висвітлити закономірність і необхідність їх прийняття в освітній діяльності; виокремити історичний етап у розвитку внутрішньої політики США “Новий курс", зосередити увагу на змінах протягом історії розвитку освіти, що спонукають до розвитку системи соціальної допомоги та 


\section{ІСТОРІЯ РОЗВИТКУ СОЦАЛЬНИХ ПРОГРАМ У США}

прийняття нових соціальних програм. Слідуючи принципу історизму, коротко проаналізувати факти, які були поштовхом до прийняття соціальних програм у США і вирішення проблем у системі освіти.

Аналіз останніх досліджень та публікацій. Розвиток соціальних програм у США започаткував Д. Рузвельт, які необхідні були для проведення соціальних реформ направлених на подолання кризи. Я. Ширмер розглядає соціальні програми, де запроваджена програма "Новий курс”, що поклала початок проведенню радикальних змін у внутрішній політиці США.

Виклад основних положень. Зміни протягом історії розвитку освіти у США мали непередбачувані напрями, зокрема те, що пуритани заснували коледжі для підготовки священників, але студенти цих коледжів залишились в історії як керівники першої в світі конституційної демократії.

Пуритани відкривають освітні заклади, в яких навчання відбувається унеформальній атмосфері, а саме більш наближеної до навчання в домашніх умовах, і виховують молоде покоління нового зразка, підкоряючись місцевим законам влади. Вони беруть участь у створенні нових навчальних закладів і намагаються виховувати людину нового зразка. Крім такого виховання людини нового зразка, у пуритан були й інші такі ж важливі освітні цілі, зокрема які стосувалися характеристик цивілізованої людини.

У 1962 р. у штаті Массачусетса (Massachusetts) законодавчі збори прийняли закон, який часто називають "Массачусетський закон про освіту" (Massachusetts Education Law). Цей закон удосконалюється і в 1852 році державний університет штату Массачусетс приймає сучасний закон "Массачусетський закон про обов'язку освіту" (Massachusetts Compulsory Education Law). Цей закон вимагає від кожного штату будувати нові навчальні заклади і впроваджувати вивчення навчальних дисциплін різного спрямування. Заслуговує на увагу те, що закон дозволяв накладати штрафи на батьків, які не займалися вихованням своїх дітей і не відправляли їх до школи [3]. Отже прийняття законів змінює освітню політику держави і призводить до затвердження нових соціальних програм в освіті.

На початку XX століття представники меншин, жінки, колишні військовослужбовці заявили про своє право навчатися у вищих навчальних закладах тому, що в університети США були засновані для навчання досить невеликої еліти населення.
Американці завжди намагались “примусити систему освіти працювати”, бо вони з великою відповідальністю ставляться до прийняття нових освітніх законів і соціальних програм. Нині населення США турбують важливі питання якості освіти, рівня обслуговування, модернізація навчальних закладів тому, що вони високо цінують вищу освіту. Висловлюючи гордо свою точку зору, вони усвідомлюють складність відповіді на поставлені питання. Для того, щоб взяти участь у дискусії, американці вивчають інформацію і вважають, що найважливішу роль в умінні спілкуватися і висвітлювати своє бачення відіграють коледжі та університети. І які б вимоги про поліпшення навчання у навчальних закладах не ставились, майбутнє гарантує їм подальший розвиток і вдосконалення освіти, зокрема освітніх соціальних програм необхідних для підвищення рівня якості фахової підготовки.

Освіта завжди поєднувала виховання i навчання молоді, тому за своєю сутністю працює на майбутнє. Майбутнє завжди виростає 3 минулого через сучасне, враховуючи своєрідність розвитку суспільства, що відбувається завдяки еволюції в освіті. І якими б складними і суперечливим не виявилися процеси їі розвитку і вдосконалення, вона займає провідне місце у сфері суспільного розвитку багатьох країн світу [8]

Давньогрецький філософ Аристотель зазначав, що до виховання потрібно ставитися з особливою увагою як у навчальних закладах освіти, так і в родині, бо кожна сім'я - це частина держави. Учений підкреслював, що сім'я в першу чергу повинна залучати дітей до освіти, культури і прищеплювати загальнолюдські норми суспільного життя, а всі державні та суспільні інституції мають підтримувати зусилля батьків.

Таким чином у США відкриваються навчальні заклади необов' язкової та обов'язкової освіти. До обов'язкової відносять школи, а до необов'язкової - коледжі, університети, зокрема дворічні громадські коледжі (community college) або професійно-технічні школи (technical school). У цих навчальних закладах студенти здобувають фах i ступінь Associate. Якщо студенти виявлять бажання навчатися у вищому навчальному закладі, тоді курси дворічного коледжу йому зараховують. Ступінь бакалавра американські студенти отримують за 4 - 5 років за умовою, що вони набирають 120 кредитів (credit hours). За статистикою таку кількість балів студенти отримують за чотири роки навчання в коледжі, зокрема $32 \%$ державних вищих навчальних закладів та 52 \% приватних [2]. Ступінь магістра (Master's degree) студенти вищих навчальних 


\section{ІСТОРІЯ РОЗВИТКУ СОЦАЛЬНИХ ПРОГРАМ У США}

закладів США отримують протягом 3 років. Він передбачає більш грунтовне вивчення навчальних дисциплін та написання наукової роботи i виконання наукових досліджень, проектів. Найвищим ступенем вищої освіти у США вважають доктора (Doctorate degree/PhD), який отримують протягом $5-7$ років навчання у вищому навчальному закладі, складання іспитів зі спеціальних навчальних і захисту дисертації [2].

Отже, вищі навчальні заклади США стають основним осередком вищої освіти США. Вирішення проблем у системі вищої освіти США засвідчує, що американці здійснили реформування освіти і успішно застосовують концепції індивідуальних освітніх програм. Зокрема, програми що стосуються ділового адміністрування або DBA (The Doctorate of Business Administration's Program) необхідні для отримання ступеня як бакалавра, так і магістра, i безумовно для кар'єрного зросту. Програми DBA включають такі теми для опанування: методологію досліджень, корпоративне лідерство, бізнес теорію та інші. Оскільки, соціальні науки допомагають студентам вищих навчальних закладів США краще зрозуміти систему освіти та економіки, зокрема бізнесу, лідерства та взаємодію цих систем всередині суспільства, тому теми для опанування фахового рівня у вищих навчальних закладах, можуть пропонувати як громади, так і уряд.

Перші соціальні програми були запроваджені президентом США Франкліним Делано Рузвельтом у 1933 році. Далекоглядний політик глибоко розумів необхідність радикальних заходів для створення в країні антикризового механізму проведення соціальних реформ направлених на подолання економічної кризи або Великої депресії в Америці, яка охоплює 1933 - 1934. Програма антикризових заходів отримала в історії країни США назву “Новий курс". Основні реформи цього курсу були проведені в перші “ста днів" президенства, коли федеральний уряд США посилив державне врегулювання банківського і фінансового секторів, скасував золотий стандарт, зокрема заборонив вільний обмін паперових грошей на золото, і створив численні організації для надання допомоги у разі виникнення надзвичайних ситуацій, розширив масштаби громадських робіт і запровадив систему допомоги фермерам. Саме тому у 1934 р. був прийнятий Закон про обіг цінних паперів, який передбачав надання рівних умов для всіх учасників торгового ринку та вільного доступу до інформації щодо діяльності компанії. Важливим є прийняття закону про відновлення промисловості у 1933 р. (National Industrial Recovery Act), який увійшов до історії
США за назвою Нерів. Цей закон надавав право асоціаціям підприємств формулювати, а президентові накладати санкції “кодексу чесної конкуренції, що передбачав правову норму, а саме: обсяг виробництва, ціни та правила збуту товару, умови праці [4].

У 1935 році у США створено систему соціального забезпечення, яка забезпечила пенсійні витрати громадянам за віком та допомогу по безробіттю. Завдання програми “Нового курсу” передбачали перерахування з федерального рівня штатам коштів на виплату соціальної допомоги особам похилого віку, безробітним, сім'ям з дітьми на утриманні, допомоги у зв’ язку з вагітністю та пологами, допомоги сліпим і покриття вартості медичних послуг.

Януш Ширмер зазначає, що запроваджена програма “Новий курс" поклала початок проведенню радикальних змін у внутрішній політиці США, у тому числі посиленню контролю за економікою та грошовими запасами з боку федерального уряду. Він підкреслює, що саме в той період були започатковані комплексні соціальні програми, а професійні спілки набули широкого визнання. У період “Нового курсу”, що охоплює 1930 - 1940 рр., коли Конгрес США прийняв велику кількість законів, що охоплюють всі сфери соціально-економічного і політичного життя країни, можна визнати періодом започаткування соціальних програм, бо саме у 1935 році було розпочато проведення широкої програми допомоги фермерам. Таким чином, створення програм соціальної допомого вказує на економічне врегулювання в країні.

Долаючи економічну кризу, США приймають нову урядову програму направлену на "Боротьбу 3 бідністю”, зокрема на виконання прийнятого в 1964 році Закону про економічні можливості. Період розвитку соціальних програм з 1950 - 1960 pp. характеризується боротьбою з бідністю тому, що саме бідність в країні становить 19\% [7]. Таким чином федеральний уряд США проводить певні заходи направлені на зменшення відсотку бідності в країні, а саме формується управління з питань цільового використання федеральних коштів на боротьбу з бідністю, розробляються і приймаються соціальні програми, зокрема “Медікер”, “Потужній cmарт”, “Корпус робочих місиь”" $i$ “Талони на харчування”. Ці програми існують і нині.

Програмам “Медікор” - програмам соціального страхування, яка направлена на надання адресної соціальної допомоги, зокрема послуги медичного страхування надаються особам віком 65 років і старше, і повністю фінансується із державного бюджету. 
“Потужній старт”- - це програмам освітньої та медичної допомоги дітям віком від 3 до 5 років 3 малозабезпечених сімей.

"Корпус робочих місиьь" $i$ “Талони на харчування” прив'язані до значень федеральних показників бідності, які розраховуються і щорічно встановлюються Міністерством охорони здоров'я США.

Долаючи економічні кризи, американці не достатньо приділяли уваги освітнім проблемам, тому доповідь “Нація в небезпеці", яку було представлено Конгресу США у 1983 році сколихнула всю країну, бо вона правдиво висвітлила стан освіти в Америці. Поступово визначалося головне завдання - взяти під контроль швидке зростання освітніх затрат, ефективне управління ресурсами i продуктивністю забезпечення навчальних закладів та галузі освіти. Педагоги й політики США усвідомлювали, що міжнародне порівняльне дослідження студентських досягнень можна застосовувати до окремих рівнів успішності у різних системах освіти. Міжнародна асоціація досліджень допомогла привернути увагу впливових зацікавлених осіб США до оцінювання знань студентів як критерію визначення результативності всієї системи освіти тим, що опублікувала результати Другого міжнародного процесу оцінювання у галузі математики, що підкреслив низький рівень досягнень студентів США [1].

3 метою підвищення рівня знань студентів США департамент освіти США заснував у 1983 році Національний комітет, зробив кілька рекомендацій щодо реорганізації навчального процесу. Зокрема головними вважалися такі: збільшити навчальний день і рік, сформувати нову основу навчального плану для того, щоб підняти стандарти знань 3 кожної дисципліни. За результатами оцінювання знань студентів США було сформульовано підвищені вимоги в оцінюванні тестів.

У 1998 році фахівці у сфері освіти та бізнесу оприлюднили Освітній Маніфест "Нація все ще у небезпеці" в якому висвітлили результати здійснених реформ, зокрема здобутки і недоліки. Національною ганьбою вони зазначаються результати III Міжнародної олімпіади з математики та природничих наук у якій американські старшокласники зайняли серед 21 запропонованих місць - 19-те з математики та 16-те з природничих наук. Таким чином у США продовжують здійснювати реформування освіти про що засвідчують прийняті закони, зокрема "Про національні цілі освіти” (1990), “Про покращання дошкільного виховання" (1990), “Про попередження відсівуучнів зі шкіл” (1991) та інші. Освітні програми США супроводжуються соціальними програмами. Соціальні програми США відрізняють за відповідними вимогами на федеральному, державному, місцевому та приватному рівнях. Вони допомагають забезпечити їжу, притулок, освіту, охорону здоров'я та гроші громадянам США через початкову і середню освіту, субсидії вищої освіти тощо. Система соціального забезпечення іноді вважається програмою соціальної допомоги та має певні характеристики, оскільки програми соціального забезпечення розроблено на підтримку населення, коли фахівці більше не працюють.

Соціальні освітні програми в Сполучених Штатах - це соціальні виплати, призначені для допомоги американським студентам навчатись у вищих навчальних закладах. Соціальні освітні програми розрізняють як федеральні, так і державні, які включають грошову допомогу, охорону здоров'я та медичні послуги, продовольчу допомогу, житлові субсидії, субсидії на освіту та комунальні послуги. Уряд США надає стипендії, субсидовані кредити більшості студентів. Ті, хто не отримують жодної допомоги, можуть отримати державну гарантовану позику, бо вартість за навчання значно зросла. Багато американців побоюються, що можуть бути виключеними із вищих навчальних закладів за несвоєчасну оплату послуг навчання, тому прогресивні демократи запропонували збільшення фінансової допомоги та надання субсидій студентам.

Нині широко відомі програми педагогічної майстерності вчителів (ТЕА), докторської програми з політології та міжнародних відносин та багато інших, які заохочують молодь до навчання [6].

Програма Педагогічної майстерності вчителів (TEA) $є$ програмою у справах освіти та культури Державного департаменту США і адмініструється Радою міжнародних наукових досліджень та обмінів (IREX). Програма TEA надає унікальну можливість вчителям загальноосвітніх шкіл Євразії та Південної Азії поглибити компетентність упредметах, які вони викладають, покращити навички викладання, дізнатись більше про США

Учасники програми відвідають Сполучені Штати Америки, щоб взяти участь у 6-тижневій програмі підвищення кваліфікації в одному 3 американських університетів. Програма підвищення кваліфікації включає навчання та 


\section{ІСТОРІЯ РОЗВИТКУ СОЦАЛЬНИХ ПРОГРАМ У США}

інтенсивний тренінг 3 методів викладання навчальної дисципліни, складання навчального плану, підходи і методи викладання в умовах рідних країн учасників, лідерства в освіті, а також навчання роботі в мережі Інтернет і електронній обробці текстів для їх використання у процесі викладання навчальної дисципліни.

Докторська програма 3 політології та міжнародних відносин (The Doctoral Programme in Political Science and International Relations) сприяє підвищенню рівня якості кваліфікації 3 прикладних досліджень. Це новаторська і всеохоплююча програма надає студентам сучасну методологічну та теоретичну підготовку 3 політології та міжнародних відносин. Завданням програми є: вдосконалити навички студентів необхідних для здійснення досліджень, зокрема підвищити рівень якості знань 3 теоретичних питань та прикладних наук, готувати студентів для проведення незалежних і оригінальних досліджень у галузі політології та міжнародних відносин.

Ця соціальна програма передбачає два етапи підвищення рівня якості знань фахівців, зокрема написання курсової роботи, підготовку i проведення лекцій на початкових курсах, що становить 60 ECTS, а також дослідницький компонент, присвячений підготовці докторської дисертації - 180 ECTS. Докторанти здобувають знання і набувають уміння, які дозволяють їм розробляти та реалізовувати найвибагливіші завдання в галузі політики та міжнародних відносин.

Після отримання докторського ступеня студенти матимуть грунтовні знання із соціальних наук, зокрема теорій, концепцій, методів дослідження тощо. Вони зможуть застосувати свої теоретичні знання з практичної діяльності. Ця програма передбачає як теоретичні, так і емпіричні дослідження. Студенти можуть отримати докторський ступінь через чотири роки навчання. Ця програмам передбачає: складання особистого плану навчання; 30 кр. спеціальних досліджень, включаючи етику дослідження; 10 кр. загальних досліджень компетентності, зокрема університетська педагогіка, керівництво, менеджмент, переговори та наукові комунікації; міжнародну мобільність, а саме: співробітництво в галузі досліджень або участь у міжнародних конференціях. Наприкінці навчання завершення наукового пошуку - написання докторської дисертації, включено рецензовані наукові публікацій або рукописи прийнятих до публікації, а також підсумковий звіт (статтю на основі дисертації); або докторську дисертацію, що $є$ завершеним науковим дослідженням і відповідає відповідним науковим критеріям, зокрема включає нові наукові і грунтовні знання у галузі досліджень та виправдані результати наукових досліджень [5].

Докторська програма з політичних, соціальних та регіональних змін - це багатопрофільна програма у галузі соціальних наук, координована факультетом соціальних наук. У докторській програмі беруть участь фахівці мистецтва, соціальних наук, сільського та лісового господарства. Дисципліни, що беруть участь у програмі, на факультеті соціальних наук дослідження розвитку, політична історія, економічна і соціальна історія та політологія. Дисципліна, що бере участь упрограмі, належить до факультету мистецтв та культурології. Дисципліна, що бере участь на факультеті сільського та лісового господарства, - це споживча економіка. Програма також включає в себе наступні міжфакультетські дослідницькі підрозділи: Центр Північних Студій, Мережа європейських студій та Інститутів [5].

Докторська програма забезпечує широку, міждисциплінарну операційну обстановку для підтримки студентів-докторів та їх керівників, а також інструментів для продуктивної співпраці між дисциплінами та дослідницькими спільнотами. Програма щорічно організовує курси, семінари та інші заходи, відкриті для всіх, зареєстрованих упрограмі. На різних програмних заходах навчаються міжнародні дослідники та власні експерти докторської програми.

Дослідницькі напрямки докторської програми повною мірою використовують підходи, теорії та методи дослідження соціальних та гуманітарних наук. Наукові сильні сторони програми включають вивчення національних та міжнародних політичних систем, мобілізації громадянського суспільства, організацій, систем управління, прийняття рішень, глобальної політики, політичної економіки, проблем розвитку, соціальних та екологічних проблем, науки про стійкість, довгострокових економічних розвиток інститутів з економіки, економічної політика, скандинавське право, соціальні мікроструктури та споживання, а також європейські студії, євразійські дослідження.

Соціальна відповідальність вищих навчальних закладів пов' язана з тим, що саме у системі вищої освіти формується інтелектуальна еліта нації. Фахівці 3 вищою освітою є показником освіченості, цивілізованості країни, іії професійного, наукового потенціалу і конкурентоспроможності. Соціально відповідальна вища освіта має забезпечити високий рівень реалізації не тільки 
традиційних - навчальної і дослідницької функцій, але і нових - інноваційної і підприємницької. В умовах українського суспільства особливу увагу треба надати виконанню культурологічної функції вищої освіти, зокрема Корпус миру.

Корпус Миру є американською урядовою організацією, яка сприяє зміцненню миру і дружби між людьми різних національностей i культур. Корпусу Миру - 50 років. Початок діяльності цієї організації датується 1961 роком. Добровольці Корпусу Миру працюють у 77 країнах в Африці, Азії, Карибському Басейні, Центральній та Південній Америці, Свропі та на Близькому Сході. У співпраці з народами інших країн добровольці працюють у галузях освіти, молодіжного та громадського розвитку, захисту довкілля та розвитку інформаційних технологій. В Україні Корпус Миру налагоджує співпрацю 3 навчальними закладами та організаціями, які прагнуть розширити свої знання про американську культуру, методи діяльності професійних організацій і учбових закладів США, та скористатися досвідом американських колег, що, у свою чергу, допоможе американцям більше дізнатися про Україну, їі культуру і українців. Корпус Миру почав налагоджувати партнерські зв'язки $з$ українським урядом та приватними організаціями у травні 1992 року.

Відповідно до угоди про співробітництво між Україною і США та з метою підвищення фахового рівня вчителів англійської мови Міністерство освіти і науки України та Корпус Миру США в Україні розпочали спільну багаторічну освітню програму підвищення фахової майстерності вчителів англійської мови. Одним із важливих аспектів даного проекту є робота американських добровольців у загальноосвітніх навчальних закладах України та обласних інститутах післядипломної педагогічної освіти. Добровольці Корпусу Миру працюють учителями англійської мови і викладачами 3 підготовки вчителів англійської мови. Вони регулярно беруть участь у місцевих заходах, які спрямовані на вирішення громадських проблем. Така діяльність передбачає літні табори для молоді, навчання дорослого населення англійської мови, навчання за місцем роботи для вчителів, а також допомогу бібліотекам, інформаційним центрам. Добровольці працюють разом з українськими колегами, їх визнають повноправними

Висновки. Основою соціальних програм в Україні та США є принципи практичної орієнтації та оптимальної достатності, науковості, системності, послідовності, автономії.

Програми соціальних наук в Україні та США забезпечують широку освіту, зокрема знання у різних сферах фахового спрямування та слугує фундаментом для отримання нових знань у галузі гуманітарних наук, мов та соціальних наук.

Соціальні програми вказують на те, що вищі заклади освіти, як соціальні інститути, несуть відповідальність за реалізацію програми, які якісно обслуговують населення, $\epsilon$ результатом досягнення. Високоосвічені та кваліфіковані фахівці $є$ показниками рівня освіти та розвитку країни, ії професійним, науковим потенціалом та конкурентоспроможністю, що також забезпечує високий рівень реалізації не тільки традиційних освітніх та дослідницьких функцій, але й нових інноваційних та підприємницьких. Особливу увагу слід приділити стратегічному розвитку країни, раціональному використанню національних ресурсів, зміцненню конкурентоспроможності країни в міжнародному співтоваристві, а також добробуту людей в умовах ринкової економіки українського суспільства.

\section{ЛITEPATУРА}

1. Allen J., Arsht L., Bennett W.J etc. A Nation still at risk. An Education Manifesto. Paper from Summit "Fifteen Years and Still a Nation at Risk". N.Y. April 3, 1998

2. How does the US education system work? Studwave (2018). - Available at: http:// studway.com.ua/sistema-osviti-ssha.

3. Jeynes, William (2007). American education history: school, society, and the common good. United States / William Jeyness. - Washigton, 2007. - 469.

4. National Industrial Recovery Act 1933. Wikipedia (2018). - Available at: https://en.wikipedia.org/wiki/ National Industrial Recovery Act of 1933

5. The Doctoral Program in Political Science and International Relations. Available at: https:// pds.ceu.edu/

6. Teaching Excellence and Achievement Program (TEA) | IREX. - Available at: https://www.irex.org/ project/teaching-excellence-and-achievementprogram-tea

7. Yanush Shirmer. The social assistance program in the USA (2018). - Available at: www.caseukraine.com.ua

8. Zvarych, I. M. (2015). Theoretical and Methodological Basic of Assessment of the Lecturers' Pedagogical Activities at the USA's Higher Educational Institutions (the second half of the XX-th - beginning of the XXI-st century). Kyiv: Manuscript, p.436.

Стаття надійшла до редакції 12.04.2018 